\title{
PERAN KEPALA SEKOLAH SEBAGAI SUPERVISOR DALAM MEMBINA PROFESIONALISME GURU
}

\section{Fitriani $^{1}$}

\begin{abstract}
In carrying out his duties as a supervisor, the principal is obliged to help the teacher provide support so that he can carry out his duties properly. To carry out his professional duties, the teacher needs to understand and appreciate the form of the student as the person he will guide. On the other hand, the teacher must also understand and appreciate the form of the children of graduates as a picture of the results of their education expected by the community in accordance with the philosophy of life and the values adopted by the Indonesian people. In improving the quality of education education must be available that has professional experts or teachers. In other words, so that education can have more use and results of use and later expected to be able to answer the above problems, then the teacher still needs guidance and direction from the principal as the leader and the person in charge of the group
\end{abstract}

Keywords: Principal as Supervisor and Teacher Professionalism

\section{PENDAHULUAN}

Pengalaman empirik menunjukkan bahwa banyak di antara orang yang telah menempuh pendidikan sarjana, menyatakan dirinya mampu dan layak menjadi guru meskipun bukan seorang sarjana pendidikan. Mereka berdalih bahwa banyak juga sarjana pendidikan justru tidak pandai atau tidak mampu menjadi guru. Pandangan seperti ini bagi mereka yang bukan sarjana pendidikan tentu wajar saja, tetapi bagaimana dengan para sarjana pendidikan?

Bagi sarjana pendidikan yang memandang jabatan guru adalah amanah dan dilakukan secara operasional, akan senantiasa terus belajar dan membuktikan bahwa pandangan dari berbagai pihak yang kurang objektif tersebut terhadap sarjana pendidikan tidaklah selamanya benar.

H. A. Malik Fadjar Mantan Menteri Pendidikan pernah melontarkan statement menarik yang intinya bahwa: "Pada saat ini di dunia pendidikan kita masih kekurangan guru, kalau tenaga pengajar banyak, tapi tenaga guru masih sangat langka..."

\footnotetext{
${ }^{1}$ Manajemen Pendidikan Islam Institut Agama Islam Negeri (IAIN) Bone.
} 
Statement ini cukup menarik untuk dicermati. ${ }^{2}$ Memang jumlah tenaga pendidik secara kuantitatif khususnya di perkotaan sudah cukup banyak, tetapi secara kualitatif sesuai bidang ilmunya belum seperti yang diharapkan. Hal inilah salah satu faktor yang menyebabkan secara umum profesionalisme kepala sekolah tenaga pendidik (guru) dan tenaga kependidikan (staf) belum sesuai dengan harapan.

Kepala sekolah dan guru harus profesional dalam melaksanakan tugas dan tanggung jawab mereka dalam pendidikan dan pengajaran. Profesional mempunyai makna yang mengacu kepada sebutan orang yang menyandang suatu profesi dan mengenai penampilan seseorang dalam mewujudkan kerja sesuai keahliannya.

Peran yang diberikan kepala sekolah akan dapat dilaksanakan dengan standar yang lebih berkualitas jika dilaksanakan oleh tenaga-tenaga profesional baik tenaga kependidikan maupun non kependidikan yang ada di madrasah dengan persyaratan kompetensi sesuai bidang tugasnya dalam pendidikan dan pengajaran. Bagi sekolah dan khususnya tenaga pendidik dalam melaksanakan tugas memberi layanan belajar perlu senantiasa mendapat penyegaran dalam bentuk bantuan teknis.

Bantuan teknis ini diberikan khususnya kepada guru sebagai upaya meningkatkan kualitasnya. Bantuan tersebut selalu dalam bentuk bantuan supervisi pendidikan yang dilakukan oleh kepala sekolah. Kenapa supervisi pendidikan diperlukan? Hal ini dilatar belakangi oleh berkembangnya science dan teknologi adanya tuntutan hak asasi manusia, pertumbuhan ekonomi, dan kemakmuran yang tidak merata, suburnya birokrasi dan sistem yang bertingkat pertumbuhan jabatan peraturan dan tuntutan negara, kultural, filosofis, psikologis, dan sosiologis dilakukan dengan cara membantu dan membina guru-guru yang kurang bermutu. Latar belakang yang demikian kompleks itu memunculkan tuntutan masyarakat akan efektifitas dan kualitas pelaksanaan pengajaran dalam penyelenggaraan pendidikan di sekolah.

${ }^{2}$ Muhaimin, Wacana Pengembangan Pendidikan Islam (Cet. 2; Jokjakarta: Pusat Studi Agama, Politik dan Masyarakat (PSAPM) bekerjasama dengan Pustaka Belajar, 2004), h.209. 


\section{PEMBAHASAN}

\section{Kepala Sekolah sebagai Supervisor}

Kepala sekolah sebagai supervisor artinya kepala sekolah berfungsi sebagai pengawas, pengendali, pembina, pengarah dan pemberi contoh kepada tenaga pendidik dan tenaga kependidikan di sekolah. Sebagai supervisor kepala sekolah harus memahami tugas dan kedudukan guru dan staf di sekolah yang dipimpinnya, sehingga kepala sekolah bukan hanya mengawasi pekerjaan dari guru dan stafnya tetapi juga membekali diri dengan pengetahuan dan pemahamannya tentang tugas dan fungsi stafnya, agar pengawasan dan pembinaan berjalan dengan baik untuk mencapai tujuan pendidikan di sekolah.

Proses pembelajaran merupakan kegiatan utama pendidikan di sekolah. Mewujudkan tujuan pembelajaran melalui aktivitas organisasi sekolah yang mengarah pada pencapaian efisisensi dan efektivitas pembelajaran. Salah satu tugas kepala sekolah adalah sebagai supervisor, yaitu memberikan pembinaan terhadap pekerjaan yang dilakukan oleh tenaga pendidik agar melaksanakan tugasnya secara profesional untuk pencapaian tujuan pembalajaran. Sergiovani dan Starrat menyatakan bahwa "Supervisiom is a process designed to help teacher an supervisor leam more abaut their practice; to better able to use their knowledge and skills to better serve parents and schools; and to make the school a more effective learning community". 3

Kutipan di atas menunjukkan bahwa supervisi merupakan suatu proses yang dirancang secara khusus untuk membantu para guru dan supervisor dalam mempelajari tugas sehari-hari di sekolah; agar dapat menggunakan pengetahuan dan kemampuannya untuk memberikan layanan yang lebih baik pada orang tua peserta didik dan sekolah, serta berupaya menjadikan sekolah sebagai masyarakat belajar yang lebih efektif.

${ }^{3}$ Mulyasa, Manajemen dan Kepemimpinan Kepala Sekolah Ed. 1 (Cet. 3; Jakarta: Bumi Aksara, 2013), h. 252. 
Supervisi dilaksanakan oleh kepala sekolah dengan melakukan pengawasan dan pengendelaian untuk meningkatkan profesionalisme tenaga pendidik maupun tenaga kependidikan. Pengawasan dan pengendalian ini merupakan kontrol agar kegiatan pendidikan di sekolah terarah pada tujuan yang telah ditetapkan. Pengawasan dan pengendalian juga dilakukan untuk mencegah agar tenaga pendidik dan tenaga kependidikan tidak melakukan penyimpangan dan selalu berhati-hati dalam melaksanakan pekerjaannya. Oleh karena itu, kepala sekolah dalam melaksanakan tugasnya sebagai supervisor harus menguasai Standar Kompetensi Pengawas.

Berdasarkan Peraturan Menteri Pendidikan Nasional Nomor 12 Tahun 2007 tentang Standar Kompetensi Pengawas, bahwa kepala sekolah selaku supervisor harus memiliki standar kompetensi, yaitu: ${ }^{4}$

a. Membimbing guru dalam menyususn silabus tiap mata pelajaran berlandarskan Kurikulum yang berlaku.

b. Membimbing guru dalam menyusun Rencana Proses Pembelajaran (RPP).

c. Membimbing guru dalam melaksanakan kegiatan pembelajaran/bimbingan.

d. Membimbing guru dalam mengelola, merawat, mengembangkan dan menggunakan media pendidikan dan fasilitas pembelajaran tiap mata pelajaran.

e. Memotivasi guru untuk memanfaatkan teknologi informasi dalam pembelajaran.

Berdasarkan kompetensi tersebut, salah satu peran utama kepala sekolah sebagai supervisor pendidikan adalah membantu atau membina guru agar lebih profesional dalam melaksanakan proses pembelajaran melalui pelaksanaan fungsi supervisi, sehingga kualitas pembelajaran menjadi lebih baik.

Jika melihat kepada fungsi supervisi, maka kepala sekolah memegang peranan yang sangat penting dalam: ${ }^{5}$

a. Membimbing guru agar dapat memahami lebih jelas masalah atau persoalanpersoalan dan kebutuhan murid, serta membantu guru dalam mengatsi suatu persoalan.

b. Membantu guru dalam mengatasi kesukaran dalam mengajar.

c. Memberikan bimbingan yang bijaksana terhadap guru baru dengan orientasi.

d. Membantu guru memperoleh kecakapan mengajar yang lebih baik dengan menggunakan berbagai metode mengajar yang sesuai dengan sifat materinya.

${ }^{4}$ Donni Juni Priansa \& Rismi Somad, Manajemen Supervisi \& Kepemimpinan Kepala Sekolah (Cet. 1; Bandung: Alfsbeta, 2014), h. 92-93.

${ }^{5}$ Binti Maunah, Supervisi Pendidikan Islam: Teori dan Praktik (Cet. 1; Yogyakarta: TERAS, 2009), h. 37 . 
e. Membantu guru meperkaya pengalaman belajar, sehingga suasana pengajaran bisa menggembirakan peserta didik.

f. Membantu guru mengerti makna alat-alat pelayanan.

g. Membina moral kelompok, menumbuhkan moral yang tinggi dalam pelaksanaan tugas sekolah pada seluruh staf.

h. Memberikan pelayanan kepada guru agar dapat menggunakan seluruh kemampuannya dalam melaksanakan tugas.

i. Memberikan pimpinan yang efektif dan demokrasi.

Kepala sekolah sebagai supervisor menjalankan perannya untuk memberikan bantuan dan bimbingan kepada guru dalam menjalankan tugasnya untuk pencapaian tujuan pembelajaran.

2. Peran Kepala Sekolah sebagai Supervisor dalam Membina Profesionalisme Guru

Adapun yang termasuk dalam pembinaan profesional guru ini meliputi:

a. Membina Profesi Mengajar

Dalam proses belajar mengajar merupakan satu kesatuan yang utuh yang tidak dapat dipisahkan antara siswa yang belajar dan guru yang mengajar. Guru merupakan profesi yang memerlukan keahlian khusus sebagai guru. Keberhasilan siswa dipengaruhi oleh kemampuan guru yang mampu mengorganisir seluruh pengalaman belajar dalam bentuk kegiatan belajar, sedangkan kepala madrasah mempunyai tugas untuk membantu, menstimulasi dan mendorong guru untuk bekerja secara profesional.

Supervisi yang dilakukan Kepala Sekolah sebagai supervisor ialah membantu guru-guru memperbaiki situasi mengajar dalam arti luas. Salah satu tugas dalam rangka meningkatkan mutu pelajaran di sekolah ialah mengembangkan dan menganalisa kurikulum yang diterapkan di sekolah. dalam rangka menganalisa kurikulum sekolah, tugas Kepala Sekolah ialah membantu guru meningkatkan profesi mengajar. ${ }^{6}$

Dalam usaha meningkatkan profesi mengajar, berkaitan dengan usaha guru membantu murid-murid dalam memperbaiki proses belajarnya. Proses belajar

${ }^{6}$ Piet A. Suhertian, Supervisi Pendidikan dalam Rangka Program in Service Education (Jakarta: Rineka Cipta, 1990), h. 84. 
mengajar yang dilakukan oleh guru tersebut merupakan suatu sistem, yaitu seperangkat objek terdiri dari komponen-komponen yang saling bergantung. Menurut analisa Suhertian bahwa situasi proses belajar mengajar itu atas dasar beberapa komponen yang perlu ditingkatkan.

Komponen-komponen tersebut mencakup beberapa hal yaitu: ${ }^{7}$

1) Membantu guru-guru melihat dengan jelas kaitan antara tujuan-tujuan pendidikan.

2) Membantu guru-guru agar lebih mampu membimbing pengalaman belajar (learning experience) dan keaktifan belajar (learning activities) murid-murid.

3) Membantu guru menggunakan sumber dan media belajar.

4) Membantu guru dalam menerapkan metode dan teknik mengajar.

5) Membantu guru dalam menganalisa kesulitan-kesulitan belajar dan kebutuhan belajar murid-murid.

6) Membantu guru dalam menilai proses belajar mengajar dan hasil belajar murid (membantu guru dalam menyusun tes yang tepat).

Dalam pembahasan ini, penulis tidak menguraikan semua komponen tersebut, namun di sini ada beberapa komponen yang sangat berpengaruh kepada aktivitas guru dalam proses belajar mengajar, yaitu: (a) membantu guru dalam persiapan mengajar dan (b) membantu dalam mengelola kelas.

Membantu guru dalam persiapan mengajar. Kegiatan guru ini di dalam dan di luar sekolah sangat menuntut kesabaran, ketekunan, kelincahan dan juga keterampilan, pengetahuan serta pengalaman. Salah satu kegiatan yang berhubungan erat dengan tugas pokoknya sebagai pengajar adalah persiapan mengajar yaitu segala sesuatunya yang harus disediakan guru dalam hubungannya dengan kegiatan mengajar, baik yang dapat diamati maupun yang bersifat abstrak.

Kepala sekolah sebagai supervisor harus membantu guru tersebut dalam membuat persiapan mengajar. Hal ini sesuai dengan fungsinya yaitu mengordinasikan adanya kerjasama untuk perbaikan dan peningkatan mutu pendidikan yang bersifat konstruktif, kreatif, kooperatif, objektif dan demokratif yang mempunyai sasaran perbaikan situasi mengajar dan situasi belajar.

${ }^{7}$ Piet A. Suhertian, Supervisi Pendidikan h. 85. 
Dalam pembinaan persiapan mengajar terdapat tiga komponen yang perlu penulis ungkapkan lebih mendalam berkaitan dengan supervisi Kepala Sekolah dalam membantu profesi mengajar guru, yakni sebagai berikut:

1) Membantu guru mengembangkan materi pelajaran. Guru dalam menyampaikan bahan pengajaran tidak hanya terpaku pada buku paket dan buku pegangan saja, akan tetapi guru dituntut untuk mengembangkan materinya dengan mencari sumber-sumber pengajaran yang lain. Hal ini dengan maksud bahwa anak didik hidup dalam lingkungan kompleks, mereka butuh perkembangan yang lebih luas. Diharapkan dengan sumber-sumber pegangan yang baru dan lebih luas dapat menjadi bahan rangsangan yang benar-benar berarti terhadap pertumbuhan anak didik. Untuk itu, guru dapat memilih bahan pengajaran dari alam sekitar dimana anak didik hidup, yang disesuaikan dengan minat kebutuhan dan kemampuan anak. Kepala sekolah dapat membantu guru untuk mengembangkan materi pelajaran dengan mencari sumber-sumber lain selain dari buku paket dan pegangan guru, seperti pemanfatan alam sekitar, majalahmajalah, surat kabar dan lain sebagainya dengan memperlihatkan hal-hal berikut: (a) sumber harus dipilih yang selaras, jangan sampai menyimpang dari program pendidikan yang ditetapkan, (b) sumber harus disesuaikan dengan kurikulum sekolah, (c) sumber harus sesuai dengan tingkat kelas, (d) sumber harus sesuai dengan kebutuhan masyarakat (orang tua murid), (e) sumber harus sesuai dengan minat dan kemampuan murid. ${ }^{8}$

2) Membantu guru dalam memahami dan menerapkan metode mengajar yang sesuai/lebih efektif.

Dalam proses belajar mengajar, seorang guru berkewajiban mengajar dengan menggunakan metode yang sebaik-baiknya yaitu dengan cara bijaksana dengan memberikan contoh yang mendidik serta dengan cara berdiskusi yang 40.

${ }^{8}$ Subari, Supervisi Pendidikan: dalam Rangka Perbaikan Mengajar(Jakarta: Bumi Aksara, 1994), h. 
baik. Metode mengajar merupakan salah satu komponen dari pada proses pendidikan, yang dalam fungsinya merupakan salah satu alat untuk mencapai tujuan. Makin baik dan sesuai metode yang digunakan, maka makin efektif pada pencapaian tujuan. Guru perlu mengenal dan mengetahui jenis-jenis metode mengajar. Selain itu juga perlu menetapkan metode yang sama dipandang tepat untuk mencapai tujuan instruksional yang telah ditetapkan.

Untuk mencapai tugas akhir tidak dapat dilakukan sekaligus melainkan harus melalui tahap-tahap tertentu yang setiap tahap harus menuju ke sasaran yang sama yakni pengabdian. Firman Allah swt. dalam QS Az-Zariyat ayat 56

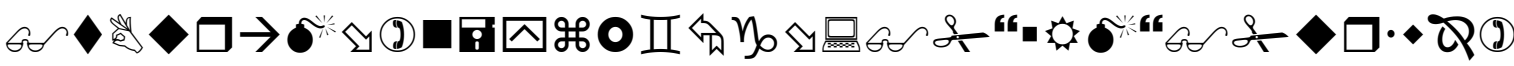

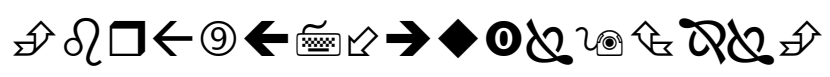

Terjemahnya: "dan aku tidak menciptakan jin dan manusia melainkan supaya mereka mengabdi kepada-Ku”.

Guru dalam melaksanakan kegiatan belajar mengajar hendaknya menyesuaikan dengan keadaan siswa yang sedang dihadapi. Dalam hal ini Abu Ahmadi dan Joko Tri Prasetyo menjelaskan bahwa ketentuan tentang metodemetode mengajar yaitu:

1) Metode ceramah

2) Metode tanya jawab

3) Metode diskusi

4) Metode pemberian tugas belajar atau resitasi

5) Metode kerja kelompok

6) Metode demonstrasi dan eksperimen

7) Metode sosio drama dan bermain peran

8) Metode karya wisata

9) Metode sistem regu (team teaching)

10) Metode proyek (unit)

Beberapa macam metode mengajar dapat digunakan dalam interaksi belajar mengajar, namun perlu diingat bahwa di antara sekian banyak metode mengajar tidak ada satupun yang dapat disebut baik dan metode yang jelek. Semua metode ini boleh dipergunakan berdasarkan kepentingan masing-masing sesuai dengan pertimbangan bahan yang akan diberikan serta kebaikan dan keburukannya masing-masing. Dengan kata lain pemilihan dan penggunaan 
metode tergantung dari niali efektivitasnya masing-masing, dan selama tidak bertentangan dengan prinsip-prinsip Islam yang mendasari metode tersebut boleh dipakai dalam pendidikan. Hal ini disebabkan semua mempunyai kelebihan dan kekurangan sendiri-sendiri. Kelebihan dan kekurangan itu dipengaruhi oleh beberapa faktor yaitu: (a) jenis bahan yang diberikan, (b) siswa yang dihadapi, (c) situasi dan kondisi pada waktu proses belajar mengajar, (d) tujuan yang akan dicapai, (e) alat bantu mengajar yang dipergunakan, dan sebagainya. Dan yang perlu diperhatikan adalah guru dalam proses belajar mengajar hendaknya menggunakan metode pengajaran lebih dari satu, sehingga kekurangan metode yang terdapat dalam metode yang satu dapat tertutupi oleh kelebihan metode yang lain.

Dari sini yang penting bagi supervisor ialah bagaimana membantu para guru agar dapat menerapkan metode-metode itu dengan baik dan efektif. Untuk itu Kepala madrasah sebagai supervisor harus betul-betul mengetahui hal yang berhubungan dengan masing-masing metode pengajaran.

3) Membantu guru dalam menggunakan alat bantu mengajar (penggunaan media pengajaran)

Menurut pendapat Hamalik yang dikutip oleh Azhar Arsyad bahwa pemakaian media pembelajaran dalam proses belajar mengajar dapat membangkitkan motivasi dan rangsangan kegiatan belajar mengajar bahkan membawa pengaruh-pengaruh psikologi terhadap siswa. Penggunaan media pembelajaran pada tahap orientasi pembelajaran akan sangat membantu kefektifan proses pembelajaran dan penyampaian pesan dari isi pelajaran pada saat itu. ${ }^{9}$

Dalam pemakaian alat peraga sebelumnya perlu diadakan pemilihan secara cermat dan usulan yang lebih banyak. Dan perlu diketahui pula bahwa

\footnotetext{
${ }^{9}$ Azhar Arsyad, Media Pembelajaran (Jakarta: Raja Grafindo Persada, 2005), h. 15.
} 
alat-alat peraga mempunyai kelebihan dan kekurangan sebagaimana metodenya. Oleh karena itu, seorang guru harus mengetahui alat peraga yang dapat digunakan untuk menjelaskan satu pelajaran. Tujuan penggunaan alat peraga adalah sama yaitu agar anak-anak memahami kata-kata karena bahasa merupakan alat komunikasi yang paling efisien.

Membantu dalam pengelolaan kelas. Dalam proses belajar mengajar terdapat dua masalah yaitu masalah pengajaran dan pengelolaan kelas. Karena antara keduanya mempunyai keterkaitan yang sangat tinggi. Artinya masalah pengajaran itu akan berhasil/tercapainya tujuan pendidikan sangat bergantung pada pengelolaan kelas. Untuk itu masalah pengelolaan kelas perlu diatur sedemikian rupa sehingga dapat menciptakan terjadinya proses belajar mengajar dalam pelaksanaannya. Tugas sehari-hari guru adalah menghadapi masalah yang bermacam-macam, hal ini disebabkan guru menghadapi berbagai macam tipe anak didik yang berbeda latar belakangnya, baik dari segi usia maupun kemampuan berfikirnya.

Berkenaan dengan masalah tersebut, Mulyadi dalam buku "Pengelolaan Kelas", membagi masalah-masalah yang terjadi dalam pengelolaan kelas menjadi dua kelompok yakni masalah perseorangan dan masalah kelompok. ${ }^{10}$ Pengelolaan kelas merupakan bagian dari tugas guru yang dibimbing oleh supervisor atau kepala madrasah. Hal ini sangat penting dalam pengajaran atau proses belajar mengajar karena dapat menentukan mutu pendidikan.

Sebagai supervisor, Kepala Sekolah dapat melakukan kegiatan prosedur untuk membina guru dalam mengelola kelas. Prosedur tersebut dapat dijadikan pedoman oleh pengajar dalam mengelola kelas agar tercipta kondisi yang optimal. Adapun prosedur yang dimaksud adalah prosedur pengelolaan kelas preventif dan prosedur pengelolaan kelas kuratif. Pengelolaan kelas preventif

\footnotetext{
${ }^{10}$ Mulyadi, Pengelolaan Kelas (Malang: IAIN Sunan Ampel, 1987), h. 26.
} 
menunjukkan pada tindakan pengajar dalam mengatur siswa dan peralatan atau format mengajar yang tepat, sehingga menumbuhkan kondisi yang menguntungkan bagi berlangsungnya proses belajar mengajar. Sedangkan pengelolaan kelas kuratif menunjukkan pada langkah-langkah yang harus diambil oleh pengajar dalam rangka mengatur siswa dan peralatan atau format belajar mengajar yang tepat setelah adanya masalah, hambatan, gangguan yang timbul dalam proses belajar mengajar di kelas. ${ }^{11}$

b. Membina Sikap Personal Profesional Guru

Sikap pribadi guru merupakan suatu sikap yang ada pada guru tersebut, tidak semua sikap guru tampak lebih baik. Ada beberapa hal yang mempunyai sikap guru dalam kehidupan, masalah yang sering dihadapi oleh guru yang berhubungan dengan sikap personalnya sebagai guru, diantaranya masalah keluh kesah (grievance), masalah kesejahteraan guru dan masalah-masalah pribadi. ${ }^{12}$

Untuk bisa membantu guru-guru, Kepala Sekolahdapat menggunakan teknik tertentu agar masalah-masalah yang dihadapi oleh guru tersebut dapat diselenggarakan tanpa menimbulkan ketidaksenjangan antar rekan sejawatnya atau dengan Kepala madrasah.

Adapun teknik-teknik atau usaha yang dilakukan Kepala Sekolah ialah:

1) Membantu dalam memecahkan masalah keluh kesah guru. Yang dimaksud keluh kesah (grievance) ialah suatu yang dialami dalam situasi kerja dimana seorang pegawai berfikir atau merasa tidak senang, tidak benar seperti yang dirasakan. Seorang guru yang mengalami berbagai macam masalah keluh kesah, sedikit banyak akan berpengaruh terhadap semangat kerjanya sebagai seorang guru atau pendidik.

Untuk mengatasi masalah tersebut Kepala Sekolah sebagai supervisor harus bertindak langsung menangani masalah-masalah yang dialami oleh guru

\footnotetext{
${ }^{11}$ Tim Dosen Universitas Negeri Malang, Manajemen Pendidikan (Malang, 2003), h. 44-45.

${ }^{12}$ Piet A. Suhertian, Supervisi Pendidikan h. 117-118.
} 
tersebut demi kelancaran tugas yang dilaksanakan yaitu dalam proses belajar mengajar. Terlebih dahulu Kepala Sekolah mengidentifikasi faktor-faktor penyebab dan keluhan-keluhan yang dihadapi. Kepala Sekolah dalam memecahkan masalah tersebut bisa dengan telaten dan berdasarkan fakta dan diusahakan guru tersebut tidak tersinggung dengan cara memahami masalah kesejahteraan guru.

2) Membantu dalam memecahkan masalah kesejahteraan guru. Beberapa teori psikologi mengemukakan tentang kebutuhan dasar manusia. Teori-teori tersebut didasarkan dari hasil penelitian yang dilakukan selama beberapa tahun. Salah satu teori yang terkenal adalah teori hierarki kebutuhan (the hierargie of need theory) yang dikemukakan oleh Abraham Maslow, bahwa kebutuhan dasar ini berkembang dari satu garis kontinu sampai pada kebutuhan pokok manusia yaitu: ${ }^{13}$

a) Kebutuhan psikologis (kebutuhan fisik)

b) Kebutuhan rasa aman (kebutuhan batin)

c) Kebutuhan sosial (masalah sosial)

d) Kebutuhan harga diri (penilaian diri)

e) Kebutuhan aktualisasi diri (kemauan seseorang untuk mengembangkan dan merealisasikan kemampuannya).

3) Membantu guru-guru dalam masalah pribadinya. Persoalan atau Problem yang dihadapi guru bukan saja terdapat di dalam kelas atau di sekolah, akan tetapi juga dari tekanan, serta pengaruh-pengaruh lainnya seperti halnya masalah pribadi. Problema atau masalah pribadi guru yang bisa ditimbulkan oleh berbagai sumber yaitu:

a) Keadaan kesehatan guru

b) Keadaan ekonomi guru

c) Keadaan kehidupan guru

d) Keadaan emosi, kejiwaan dan pengalaman-pengalaman spiritual guru.

Sebagai Kepala Sekolahdapat mengambil tindakan-tindakan yang bisa membantu agar masalah yang dihadapi oleh guru dapat teratasi.

${ }^{13}$ Ibrahim Bafadal, Supervisi Pengajaran: Teori dan Aplikasinya dalam Membina Profesional Guru (Jakarta: Bumi Aksara, 1992), h. 64. 
Menurut Nawawi yang dikutip oleh Djumhur bahwa untuk mengembangkan kualitas profesional guru melalui supervisi, Kepala sekolah melakukan kegiatan, yaitu 1) Pendidikan In-Service dan 2) Pendidikan On-Service (kelompok kesejawatan).

1) Pendidikan In-Service Training adalah semua usaha pendidikan dan pengalaman untuk meningkatkan keahlian guru dan pegawai guna menyelaraskan pengetahuan dan keterampilan mereka dengan kemajuan dan perkembangan ilmu pengetahuan dalam bidangnya masing-masing. In-Service Training merupakan suatu tuntutan untuk meningkatkan mutu pendidikan. ${ }^{14}$

Dalam melakukan supervisi, Kepala Sekolah harus berusaha mencari kesempatan agar guru-guru yang dipimpinnya memperoleh penataran atau InService Training. Kegiatan ini dilakukan sebagai usaha meningkatkan kemampuan guru sambil menjalankan tugas, agar berkembang sesuai dengan perkembangan terakhir dalam bidangnya.

2) Pendidikan On-Service, adalah pendidikan yang dilakukan melalui kelompok kesejawatan dengan tujuan untuk membina dan mengembangkan profesi guru, yakni dengan mengadakan perkumpulan guru dalam bidang studi dari beberapa sekolah bertemu sekolah yang dijadikan sebagai pusat pembahasan (sanggar kerja) atau kelompok kerja guru. ${ }^{15}$

Dengan kata lain, pengembangan on-service ini dihimpun dalam wadah pertemuan yang dikembangkan berdasarkan studi atau rumpun bidang masingmasing sekolah yang tergabung dalam kelompok kesejawatan dimana anggota yang memiliki pangkat tertinggi dalam setiap rumpun diharapkan berfungsi sebagai pembimbing.

Seorang supervisor perlu menyadari akan pentingnya pendidikan atau latihan in-service atau on-service dalam proses pembinaan dan pengembangan

\footnotetext{
${ }^{14}$ Djumhur dkk, Bimbingan dan Penyuluhan di Sekolah (Bandung: t.th), h. 115.

${ }^{15}$ Ibihur dkk, Bimbingan dan Penyuluhan di Sekolah h. 120.
} 
orang-orang yang disupervisi. Para guru yang disupervisi menyadari bahwa kegiatan tersebut merupakan bagian integral dalam proses dan latihan inservice maupun pelatihan dalam kelompok kesejawatan sebagai suatu penyelenggaraan mutlak diperlukan dalam setiap program supervisi pendidikan modern. dengan demikian para guru selalu up-to date, tidak merasa ketinggalan zaman.

\section{PENUTUP}

Kepala Sekolah sebagai supervisor mempunyai peran yang sangat penting dalam membina profesionalisme guru. Adapun pembinaan yang dilakukan oleh kepala sekolah adalah membina profesi mengajar dan membina sikap personal profesionalisme guru.

\section{DAFTAR RUJUKAN}

Arsyad, Azhar. Media Pembelajaran. Jakarta: Raja Grafindo Persada, 2005.

Djumhur dkk, Bimbingan dan Penyuluhan di Sekolah Bandung: t.th

Ibrahim Bafadal, Supervisi Pengajaran: Teori dan Aplikasinya dalam Membina Profesional Guru.Jakarta: Bumi Aksara, 1992

Maunah, Binti. Supervisi Pendidikan Islam: Teori dan Praktik. Cet. 1; Yogyakarta: TERAS, 2009.

Muhaimin. Wacana Pengembangan Pendidikan Islam. Cet. 2; Jokjakarta: Pusat Studi Agama, Politik dan Masyarakat (PSAPM) bekerjasama dengan Pustaka Belajar, 2004.

Mulyadi, Pengelolaan Kelas. Malang: IAIN Sunan Ampel, 1987

Mulyasa, Manajemen dan Kepemimpinan Kepala Sekolah Ed. 1, Cet. 3; Jakarta: Bumi Aksara, 2013.

Priansa, Donni Juni \& Rismi Somad. Manajemen Supervisi \& Kepemimpinan Kepala Sekolah. Cet. 1; Bandung: Alfsbeta, 2014.

Subari, Supervisi Pendidikan: dalam Rangka Perbaikan Mengajar. Jakarta: Bumi Aksara, 1994

Suhertian, Piet A. Supervisi Pendidikan dalam Rangka Program in Service Education. Jakarta: Rineka Cipta, 1990.

Tim Dosen Universitas Negeri Malang, Manajemen Pendidikan. Malang, 2003. 
P-ISSN: 2407-8107 E-ISSN: 2685-4538 